\title{
Induced aeration flow over stepped spillways: mean pressures, air entrainment and flow behavior
}

\author{
Aeração induzida em vertedouros em degraus: pressões médias, \\ entrada de ar e comportamento do escoamento
}

Carolina K. Novakoski ${ }^{1}$ (D), Rute Ferla ${ }^{2}$ (D), Priscila dos Santos Priebe ${ }^{2}$ (D), Aline Saupe Abreu ${ }^{2}$ (D), Marcelo G. Marques ${ }^{2}$ (D), Maurício Dai Prá2, Alba V. B. Canellas ${ }^{3} \&$ Eder D. Teixeira $^{2}$

${ }^{1}$ Coordenadoria Acadêmica, Universidade Federal de Santa Maria, Cachoeira do Sul, RS, Brasil ${ }^{2}$ Instituto de Pesquisas Hidráulicas da Universidade Federal do Rio Grande do Sul, Porto Alegre, RS, Brasil

${ }^{3}$ Furnas Centrais Elétricas S.A., Rio de Janeiro, RJ, Brasil

E-mails: ckn.carolina@gmail.com (CKN),ruteferla@hotmail.com (RF),proscilaspriebe@gmail.com (PSP), alsaupe@gmail.com (ASA), mmarques@iph.ufrgs.br (MGM), mauricio.daipra@ufrgs.br (MDP), alba@furnas.com.br (AVBC), eder.teixeira@ufrgs.br (EDT)

\begin{abstract}
Stepped spillways can dissipate a great amount of energy during the flow passage over the chute, however these structures have limited operation due to the risk of cavitation damage. The induced aeration may protect the concrete chute through the air concentration near the channel bottom. Furthermore, some research studies have indicated that the presence of air in flows may reduce the mean pressures. The present research aims to analyze mean pressures, air entrainment coefficient and flow behavior over a stepped spillway with aeration induced by two different deflectors, comparing the results to natural aeration flow. Despite the jet impact influence, the induced aeration does not change significantly the mean pressures compared to natural aeration flow. The air entrainment coefficient, as well as the jet impact position, is higher for the deflector with the longer extension and, although air bubbles can be seen throughout the extension of the chute due to the air entrainment through the inferior flow surface, the induced aeration did not anticipate the boundary layer inception point position.
\end{abstract}

Keywords: Deflector; Physical modelling; Flow aeration.

\section{RESUMO}

Vertedouros em degraus dissipam uma grande quantidade de energia durante a passagem do escoamento pela calha, porém essas estruturas tem sua operação limitada devido a riscos de danos por cavitação. A aeração induzida pode agir protegendo a calha de concreto através da concentração de ar próximo ao fundo do canal. Além disso, algumas pesquisas têm indicado que a presença de ar em escoamentos pode reduzir as pressões médias. A presente pesquisa tem por objetivo analisar as pressões médias, coeficiente de entrada de ar e o comportamento do escoamento sobre uma calha em degraus com dois diferentes defletores, comparando os resultados com um escoamento com aeração natural. Além da influência no ponto de impacto do jato, a aeração induzida não alterou, significantemente, as pressões medias em relação a um escoamento com aeração natural. O coeficiente de entrada de ar, assim como a posição de impacto do jato, é maior para o defletor mais extenso e, embora bolhas de ar possam ser identificadas ao longo de toda a extensão da calha, devido à entrada de ar através da superfície inferior do escoamento, a aeração induzida não antecipou a posição de afloramento da camada limite.

Palavras-chave: Defletor; Modelagem física; Aeração de escoamentos. 


\section{INTRODUCTION}

Stepped spillways are structures that provide the security of the dam allowing energy dissipation, which reduces the dimensions of the downstream stilling basin. In addition, since the decade of 1970, the development of the technique of Roller Compacted Concrete (RCC) has brought considerable benefits for the construction process, which lead to several researches about this subject such as Tozzi (1992), Christodoulou (1993), Chanson (1994), Chamani \& Rajaratnam (1999), Matos (1999), Chanson (2001), Boes \&Hager (2003), Ohtsu et al.(2004), Simões et al. (2013), Frizell et al.(2013), Matos \& Meireles (2014), Zhang et al. (2016), among others.

Despite the advantage of energy dissipation and ease of construction of stepped spillways, these structures cannot be utilized with specific discharges over approximately $15 \mathrm{~m}^{2} / \mathrm{s}$, according to Amador et al. (2009), Gomes (2006) and Novakoski et al. (2018). This limit was proposed considering the risk of the occurrence of cavitation, a phenomenon related to low pressure flows and high velocities, and which may cause serious damage to hydraulic structures.

Considering that increasing the discharge capacity to flow over stepped spillways allows the use of lesser length spillways, which represents a construction economy and considering the tendency of the construction of higher discharges spillways, some studies have been carried out aiming to anticipate the presence of air in the flow. It is known that the air concentration near the bottom of the chute can reduce or even prevent cavitation damage. Peterka (1953) demonstrated that $2 \%$ of air concentration reduced significantly and $8 \%$ eliminated the damage caused by cavitation. Semenkov \& Lentyaev (1973) suggested that the stronger the concrete, the less need for air concentration. According to the authors, considering a $40 \mathrm{MPa}$ concrete, $3 \%$ of air concentration is needed to eliminate cavitation damage. Russell \& Sheehan (1974) proposed that 5\% of air concentration is sufficient to avoid cavitation damage even in situations where strong concrete structures would suffer damage. Additionally, some studies have demonstrated that the presence of air in the flow may increase the pressures in it, which reduces the risk of cavitation occurrence. Dong et al. (2007) measured the mean pressures in a closed conduit with velocities between 20 and $50 \mathrm{~m} / \mathrm{s}$ and air concentrations between 0 and $14 \%$, concluding that the air concentration increase causes a significant elevation in the mean pressures.

Air can be inserted into the flow by aerator elements such as piers and deflectors combined with an air supply system. Authors such as Dong et al. (2019), Koen et al. (2019), Ma \& Wu (2021) and Priebe et al. (2021) studied the aeration induced in stepped spillways by piers and Pfister et al. (2006a), Pfister et al. (2006b), Mojtaba et al. (2015), Terrier (2016), Novakoski et al. (2020) and Ferla et al. (2021) with deflectors.

A parameter widely used to verify the performance of aerators is the air entrainment coefficient $(\beta)$, demonstrated in Equation 1, where $\mathrm{Q}_{\mathrm{w}}$ is the water flow discharge and $\mathrm{Q}_{\mathrm{a}}$ is the air flow discharge. It is important to emphasize that $\beta$ considers only the air entrance through the aerator elements and not the air-water changes through the free surface. Some authors who proposed equations which allows estimating this coefficient for different kinds of aerators elements are Kökpınar \& Gogus (2002), Zamora et al. (2008), Pfister and Hager (2010), Terrier (2016) and Ferla et al. (2021). Generally, the equations proposed are a function of Froude number, aerator geometry, flow depth, mean flow velocity, or the reach of the jet. Equation 2 shows Terrier (2016) proposal for a deflector aerator, as a function of the jet impact position $\left(\mathrm{L}_{\mathrm{jet}}\right)$ and the flow depth $\left(\mathrm{h}_{\mathrm{o}}\right)$.

$\beta=\frac{Q_{a}}{Q_{w}}$

$\beta=0.0077 \frac{L_{j e t}}{h_{o}}$

Among the authors who have studied the same aerator type (deflectors combined with an air supply system) in stepped spillways, distinct flow behaviors were observed along the chute. Figure 1a shows the flow behavior observed by Pfister et al. (2006a), in which a blackwater core is formed by the jet reaching the chute steps. In this case, the free surface aeration begins before the blackwater core end. The flow behavior demonstrated in Figure $1 \mathrm{~b}$ was obtained by Terrier (2016). The blackwater core is also formed along the jet, however, when it reaches the stepped chute, the flow is already fully aerated. Novakoski et al. (2020) observed a flow that, as well as Pfister et al. (2006a), contains
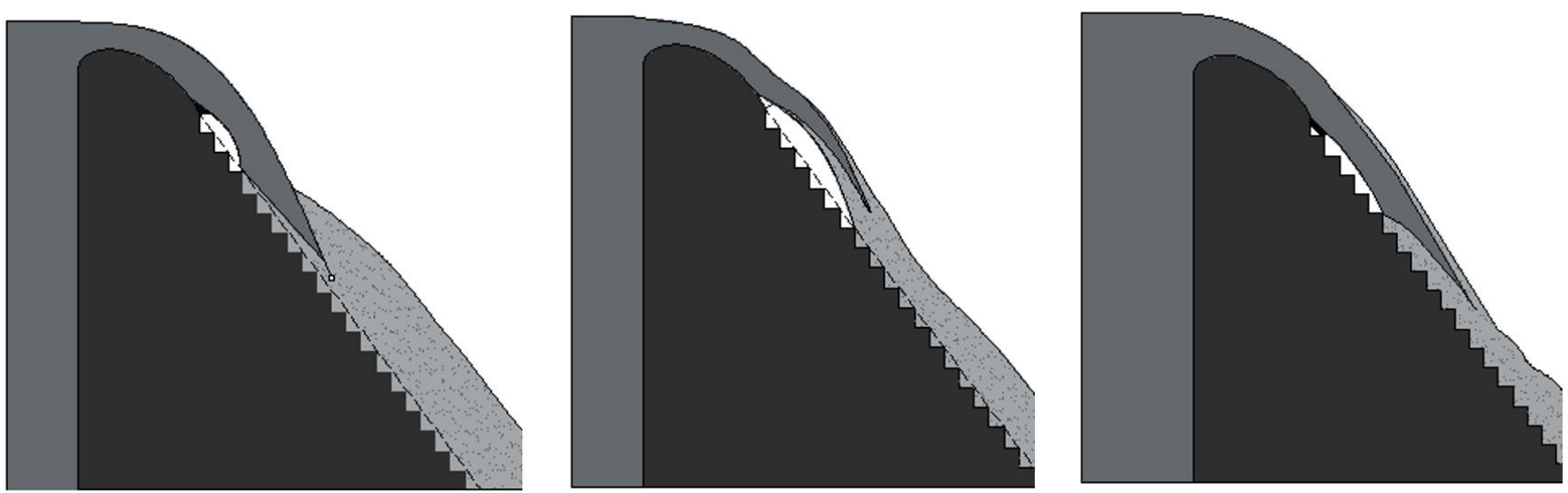

Figure 1. Flow behavior according to different authors. 
a blackwater core which extends over the steps, but the free surface aeration begins downstream the core end, originating a transition zone. The differences in flow behavior pointed out by each of the above-mentioned authors are mainly related to the distinctions in the respective devices, as well as the specific flow rates tested and the aerators geometry. The flow behavior influences its parameters, such as the pressures on the chute and the air concentration in the flow.

Considering the above-mentioned, the present paper aims to analyze mean pressures, the air entrainment coefficient and the flow behavior over a stepped spillway, considering aeration induced by a deflector and an air supply chamber.

\section{EXPERIMENTAL SETUP AND INSTRUMENTATION}

The hydraulic model utilized to conduct the experiments is located at the Laboratório de Obras Hidráulicas (IPH - UFRGS) and consists in a Creager type ogee crest followed by a $0.50 \mathrm{~m}$ wide chute with 52 steps of $0.06 \mathrm{~m}$ high (without transition steps) and $53^{\circ}$ slope. A structure scheme and the adopted parameters are shown in Figure 2, as well as the two different deflectors geometry tested. In Figure 2, $\mathrm{h}_{\mathrm{c}}$ is the critical flow depth, $\mathrm{h}_{\mathrm{o}}$ is the flow depth
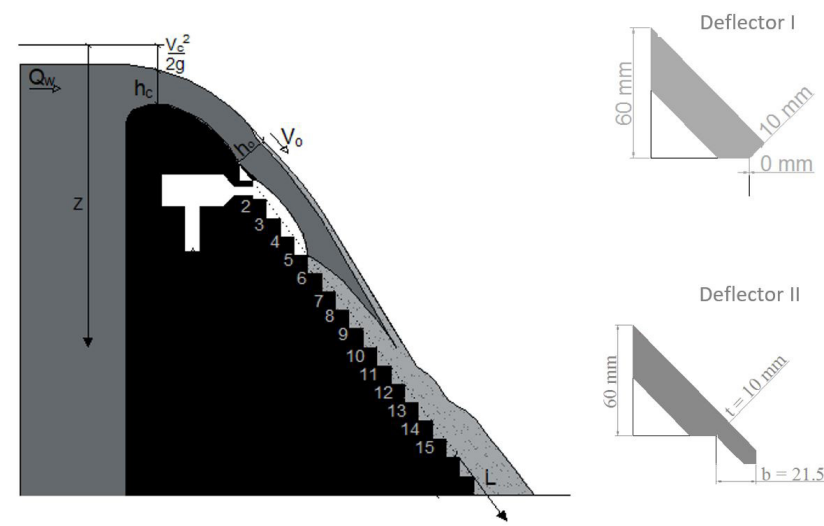

Figure 2. Physical model scheme and deflectors geometry tested.

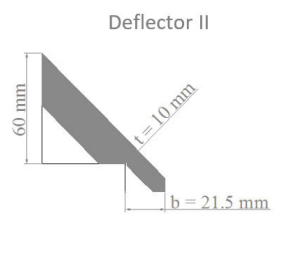

at the intersection of ogee and deflector $\mathrm{g}$ is the acceleration of gravity; $\mathrm{Q}_{\mathrm{w}}$ is the water discharge, $\mathrm{V}_{\mathrm{c}}$ is the critical flow velocity, $\mathrm{V}_{\mathrm{o}}$ is the flow velocity at the intersection of ogee and deflector, $\mathrm{Z}$ is the flow energy on the point analyzed. The induced aeration is provided by a deflector positioned on the first step of the chute and an air supply chamber connected to a slot immediately below the deflector. Tests without aerator elements (natural aeration) were also conducted to serve as a reference allowing the comparison with induced aeration.

The specific discharges tested were $0.20,0.30,0.40$ and $0.50 \mathrm{~m}^{2} / \mathrm{s}$ which, considering a hypothetical model-prototype scale of 1:15 with Froude similarity, corresponds to 11.6, 17.4, 23.2 and $29.0 \mathrm{~m}^{2} / \mathrm{s}$. The measurements performed were mean pressures, mean velocities of the air entrance into the aerator system and flow depths. The mean pressures were measured through pressure transducers (Omega PX419, Sitron SP96 and Hytronic TM25) installed near the edges of the vertical and horizontal faces of the steps, as Figure 3a exemplifies for step 6, as recommended by Amador et al. (2009), Sánchez-Juny et al. (2007), Osmar et al. (2018) and Tassinari et al. (2020). The air entrance velocity was measured by a Pitot-Prandtl probe (Dwyer 166-12) coupled to a differential pressure transducer (Rücken RTBP-420-DIF). The Pitot-Prandtl probe was located inside a $0.70 \mathrm{~m}$ long air duct with an internal diameter of $0.069 \mathrm{~m}$ connected to the air chamber, as shown in Figure 3b.

The flow depth $\left(\mathrm{h}_{\mathrm{o}}\right)$ and Froude $\left(\mathrm{F}_{\mathrm{r}}\right)$, Reynolds $\left(\mathrm{R}_{\mathrm{e}}\right)$ and Webber $\left(\mathrm{W}_{\mathrm{e}}\right)$ numbers (Equations 3, 4 and 5) were calculated at the intersection of the ogee and the deflector (Table 1, Figure 2). In Equations 3, 4 and 5, $\sigma_{\mathrm{w}}$ is the superficial tension of the fluid, $\varrho$ is the water density, $\nu$ is the kinematic viscosity of the flow. In order to verify the scale effects, Figure $4 \mathrm{a}$ and Figure $4 \mathrm{~b}$ present, respectively, Reynolds and Webber numbers compared to the limits proposed by Kobus (1984), Koschitzky et al. (1984), Rutschmann \& Hager (1990), Amador (2005) and Takahashi et al. (2005), above which the scale effects can be negligible. The limits of Koschitzky et al. (1984), Kobus (1984), Rutschmann \& Hager (1990) and Takahashi et al. (2005) are related to the air entrainment coefficient estimate and Amador (2005) to pressures measures. Only the discharge of $0.20 \mathrm{~m}^{2} / \mathrm{s}$ doesn't reach the limit indicated



Figure 3. Pressures and air discharge measurements 


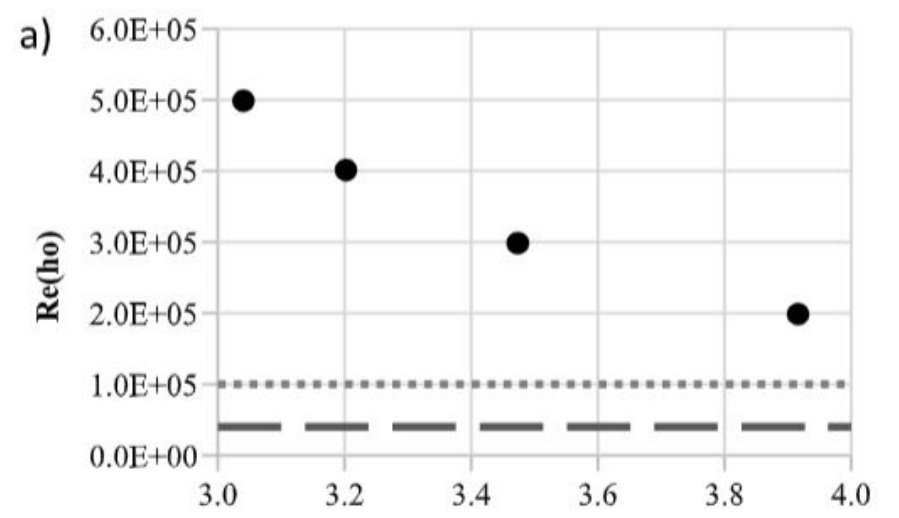

Re (ho)

Fr (ho)

" " $\beta$ - Koschitzky (1987) =kobus (1984) = Amador (2005)

- $\beta$ - Takashi et al. (2005)

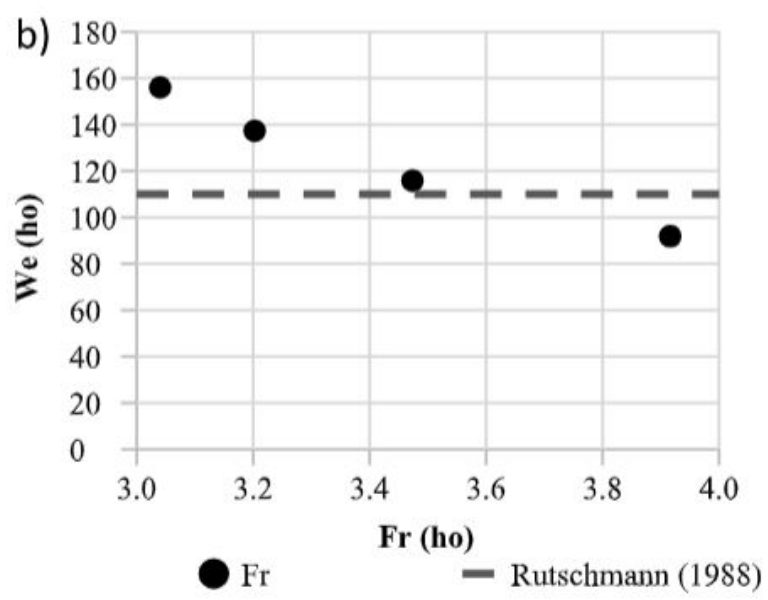

Figure 4. Reynolds (a) and Webber (b) numbers calculated at the intersection of ogee and deflector.

Table 1. Froude, Reynolds and Webber numbers calculated at deflector beginning.

\begin{tabular}{cccccc}
\hline $\begin{array}{c}\mathbf{q} \\
\left(\mathbf{m}^{2} / \mathbf{s}\right)\end{array}$ & $\mathbf{h}_{\mathbf{o}} \mathbf{( m )}$ & $\begin{array}{c}\mathbf{V}_{\mathbf{o}} \\
(\mathbf{m} / \mathbf{s})\end{array}$ & $\mathbf{F}_{\mathbf{r}}\left(\mathbf{h}_{\mathbf{o}}\right)$ & $\mathbf{R}_{\mathrm{e}}\left(\mathbf{h}_{\mathbf{o}}\right)$ & $\mathbf{W}_{\mathrm{e}}\left(\mathbf{h}_{\mathrm{o}}\right)$ \\
\hline 0.20 & 0.064 & 3.103 & 3.92 & $2.00 \times 10^{5}$ & 91.87 \\
0.30 & 0.091 & 3.282 & 3.47 & $3.00 \times 10^{5}$ & 115.87 \\
0.40 & 0.117 & 3.431 & 3.20 & $4.00 \times 10^{5}$ & 137.36 \\
0.50 & 0.140 & 3.563 & 3.04 & $5.00 \times 10^{5}$ & 156.03 \\
\hline
\end{tabular}

by Rutschmann \& Hager (1990) and may be prone to major scale effects.

$$
\begin{aligned}
& F_{r o}=\frac{v_{o}}{\sqrt{g \cdot h_{o}}} \\
& W_{e}=\frac{V_{o}}{\left(\sigma_{w} / \rho h_{o}\right)^{0.5}} \\
& R_{e}=\frac{v_{o} h_{o}}{v}
\end{aligned}
$$

\section{RESULTS AND DISCUSSIONS}

\section{Pressure measurements}

The mean pressures $\left(\mathrm{P}_{\mathrm{m}}\right)$ measured at the edge of vertical (V) and horizontal $(\mathrm{H})$ faces of the steps with natural aeration (NA) and induced aeration with the two deflectors tested are presented in Figure 5, considering the two extreme specific discharges tested $\left(0.20\right.$ and $\left.0.50 \mathrm{~m}^{2} / \mathrm{s}\right)$. It can be noted that, upstream from jet impact on the chute, the relative pressures are practically null (atmospheric pressure), which indicates that the jet's characteristics are influenced only by the deflector and air chamber geometry and flow discharge. A more detailed analysis of the pressure under the flow jet is presented in Appendix A. At the jet impact point (step 6 for deflector I and step 9 for deflector II), a peak of positive pressures can be seen for both vertical and horizontal faces of steps and, downstream the jet impact, the pressures tend to reach the natural aeration values. The pressures observed on horizontal faces are positive, while the pressures on vertical faces are minor and oscillate between negative and positive values. Observing the jet impact on vertical and horizontal faces, it was noted that the pressure peak has occurred in the same step number (6 for deflector I and step 9 for deflector II), probably due to the vortice formation between the horizontal and the immediately anterior vertical face of the step.

Comparing the deflector geometry tested, deflector II presented a jet impact downstream (step 9), related to deflector I (step 6). However, downstream from the jet impact influence no differences can be noted among the pressures associated with each deflector and natural aeration. The jet impact influence extends downstream from the jet impact position up to approximately step 10 with deflector I and step 14 with deflector II, regardless of the tested discharge. That influence was verified through the difference between the pressures in natural and induced aeration.

The pressures presented in Figure 5, related to deflectors I and II, are shown in Figure 6 (horizontal faces) and Figure 7 (vertical faces), represented by $\frac{P_{m} / \gamma}{Z}$, as suggested by Canellas et al. (2017), as a function of the chute position represented by $\frac{\mathrm{L}-\mathrm{L}_{\text {jet }}}{\mathrm{h}_{\mathrm{o}}}$. $\frac{\mathrm{Pm}}{\gamma}$ is the mean pressure, $\mathrm{Z}$ is the energy of the point analyzed, $\mathrm{L}$ is the distance along the chute from the first step to the point analyzed, $\mathrm{L}_{\text {jet }}$ is the distance along the chute between the first step and the jet impact position observed on the horizontal face and $h_{o}$ is the flow depth at the deflector beginning. Figure 6 refers to the horizontal faces of steps while Figure 7 refers to the vertical ones. The upper and lower envelope curves were adjusted through the quantile regression of $95^{\text {th }}$ and $5^{\text {th }}$ percentile, and are presented, 
a)

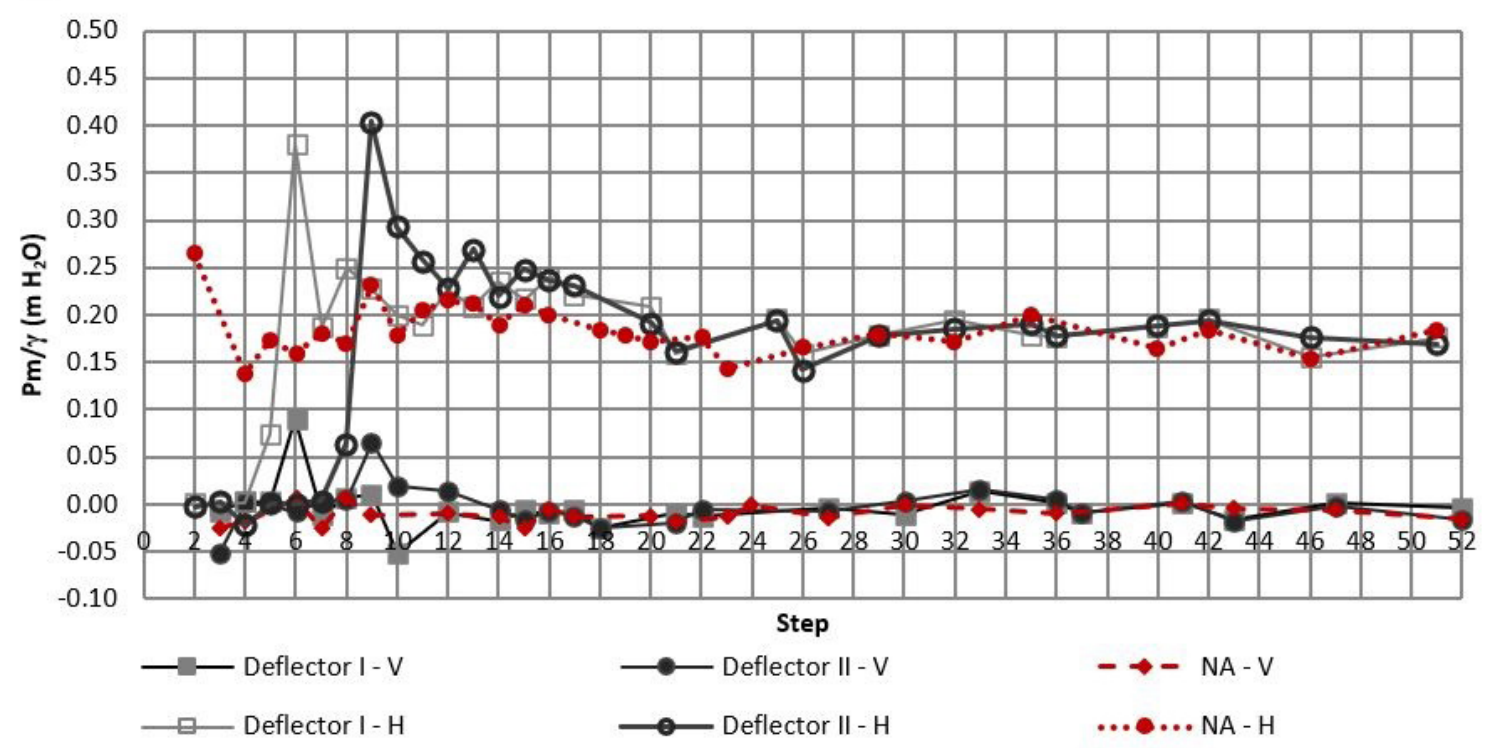

b) 0.50

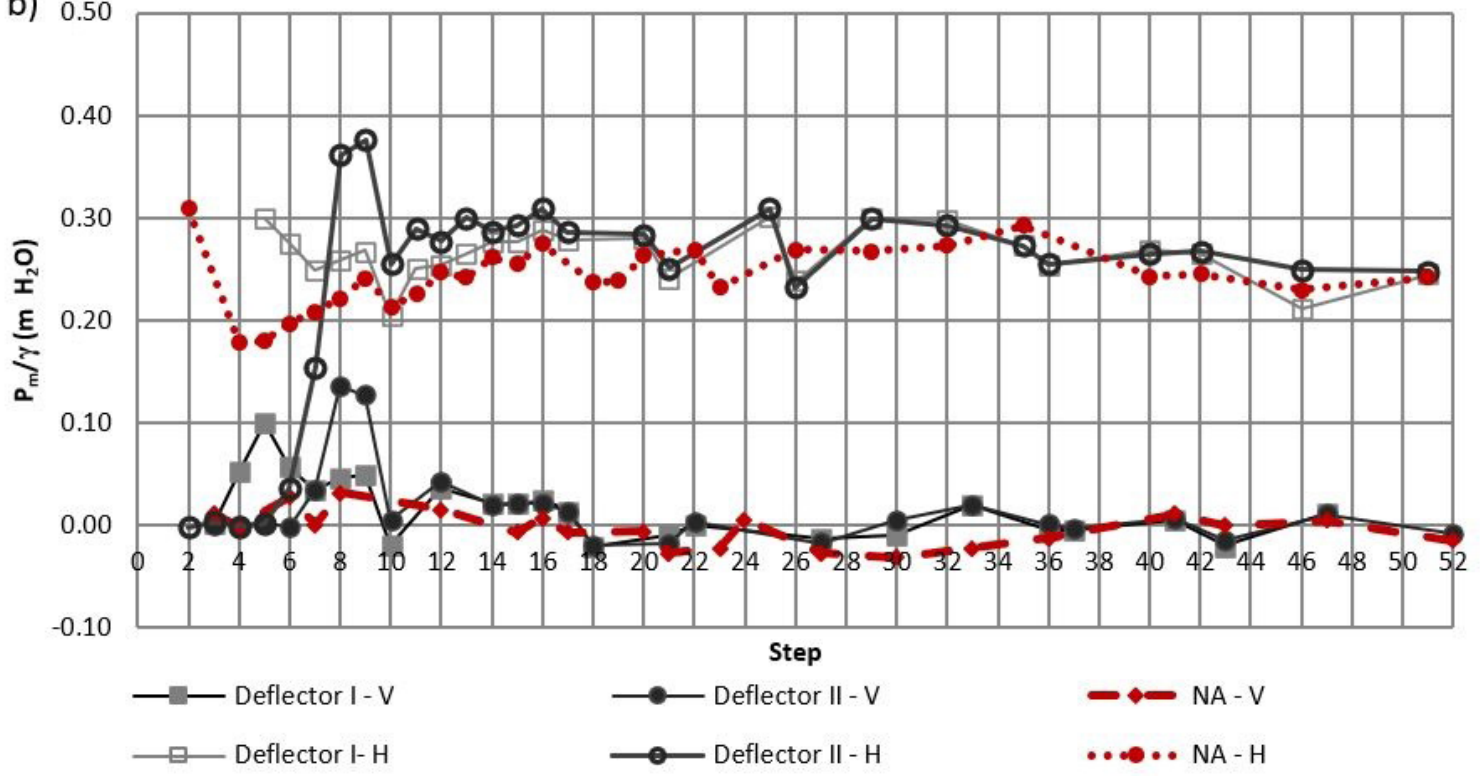

Figure 5. Mean pressures at the edges of horizontal and vertical faces of the steps for the discharges (a) $0.20 \mathrm{~m}^{2} / \mathrm{s}$, (b) $0.50 \mathrm{~m}^{2} / \mathrm{s}$.

respectively, in Equation 6 and 7 related to horizontal faces of steps and 8 and 9 , related to vertical faces.

$\frac{\boldsymbol{P}_{\boldsymbol{m}} / \gamma}{\boldsymbol{Z}}=3.09\left(\frac{\boldsymbol{L}-\boldsymbol{L}_{\boldsymbol{j e t}}}{\boldsymbol{h}_{\boldsymbol{o}}}+27.6\right)^{-0.595}$

$\frac{\boldsymbol{P}_{\boldsymbol{m}} / \gamma}{\boldsymbol{Z}}=50.6\left(\frac{\boldsymbol{L}-\boldsymbol{L}_{\boldsymbol{j e t}}}{\boldsymbol{h}_{\boldsymbol{o}}}+192.7\right)^{-1.030}$

$\frac{\boldsymbol{P}_{\boldsymbol{m}} / \gamma}{\boldsymbol{Z}}=\frac{0.14}{1+\left(\frac{\boldsymbol{L}-\boldsymbol{L}_{\boldsymbol{j e t}}}{14.66 \boldsymbol{h}_{\boldsymbol{o}}}\right)^{1.58}}$

$$
\frac{\boldsymbol{P}_{\boldsymbol{m}} / \gamma}{\boldsymbol{Z}}=-4.71 \times 10^{-6}\left(0.978^{\frac{\boldsymbol{L}-\boldsymbol{L}_{\boldsymbol{j e t}}}{\boldsymbol{h}_{\boldsymbol{o}}}}\right)\left(\frac{\boldsymbol{L}-\boldsymbol{L}_{\boldsymbol{j e t}}}{\boldsymbol{h}_{\boldsymbol{o}}}\right)^{2.236}
$$

In contrast to Dong et al. (2007) results, the mean pressure values found in the present study have not shown an elevation with the insertion of air through induced aeration. A possible explanation is that the results of Dong et al. (2007) were conducted in a closed conduit, where there was no space allowing flow expansion, which exists on the chute where the present research tests were conducted. Another possible explanation is the quantity of air inserted into the flow, which may not be sufficient to modify 


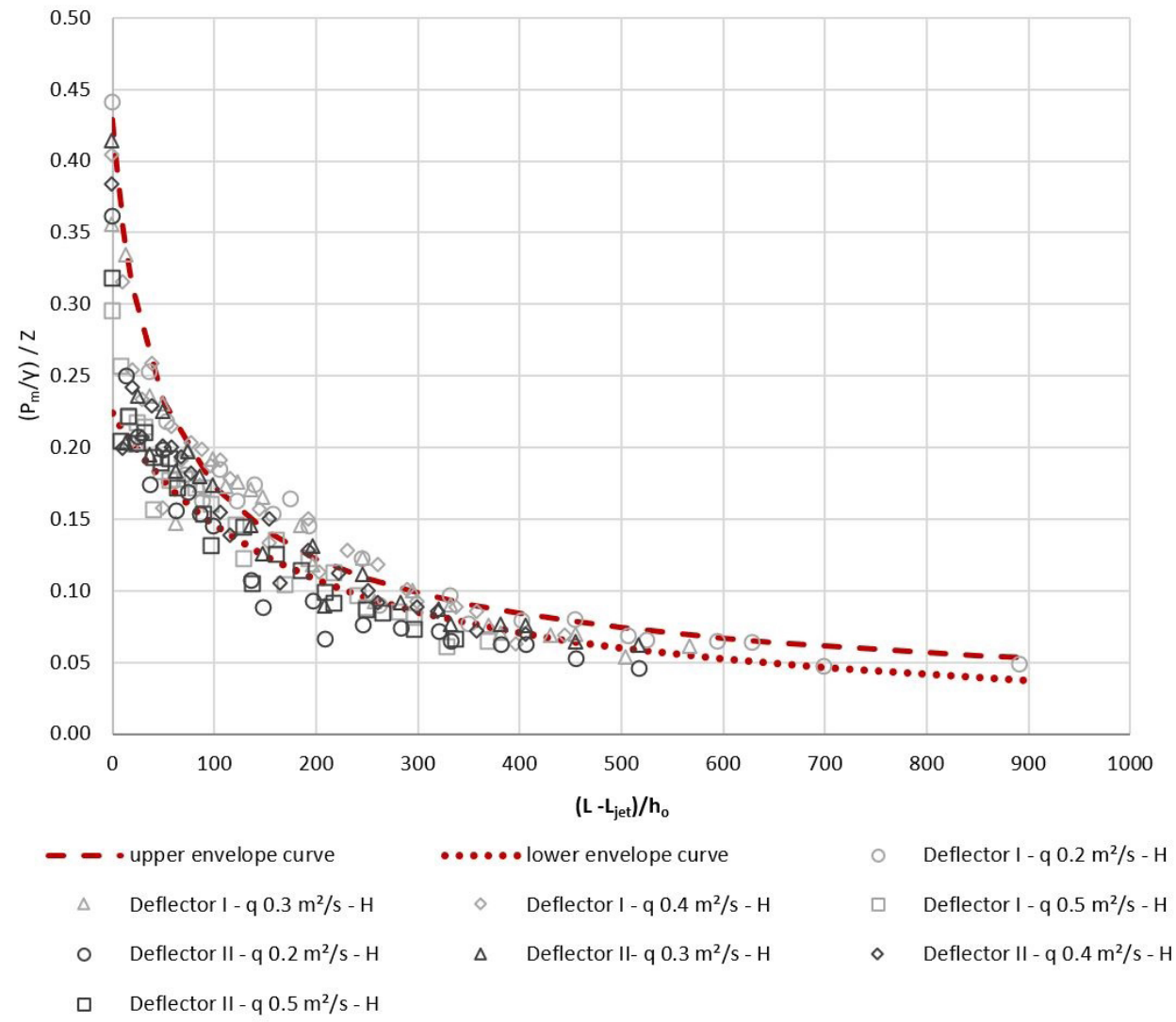

Figure 6. Mean pressures obtained in horizontal faces of steps for deflector I and II, dimensionless.

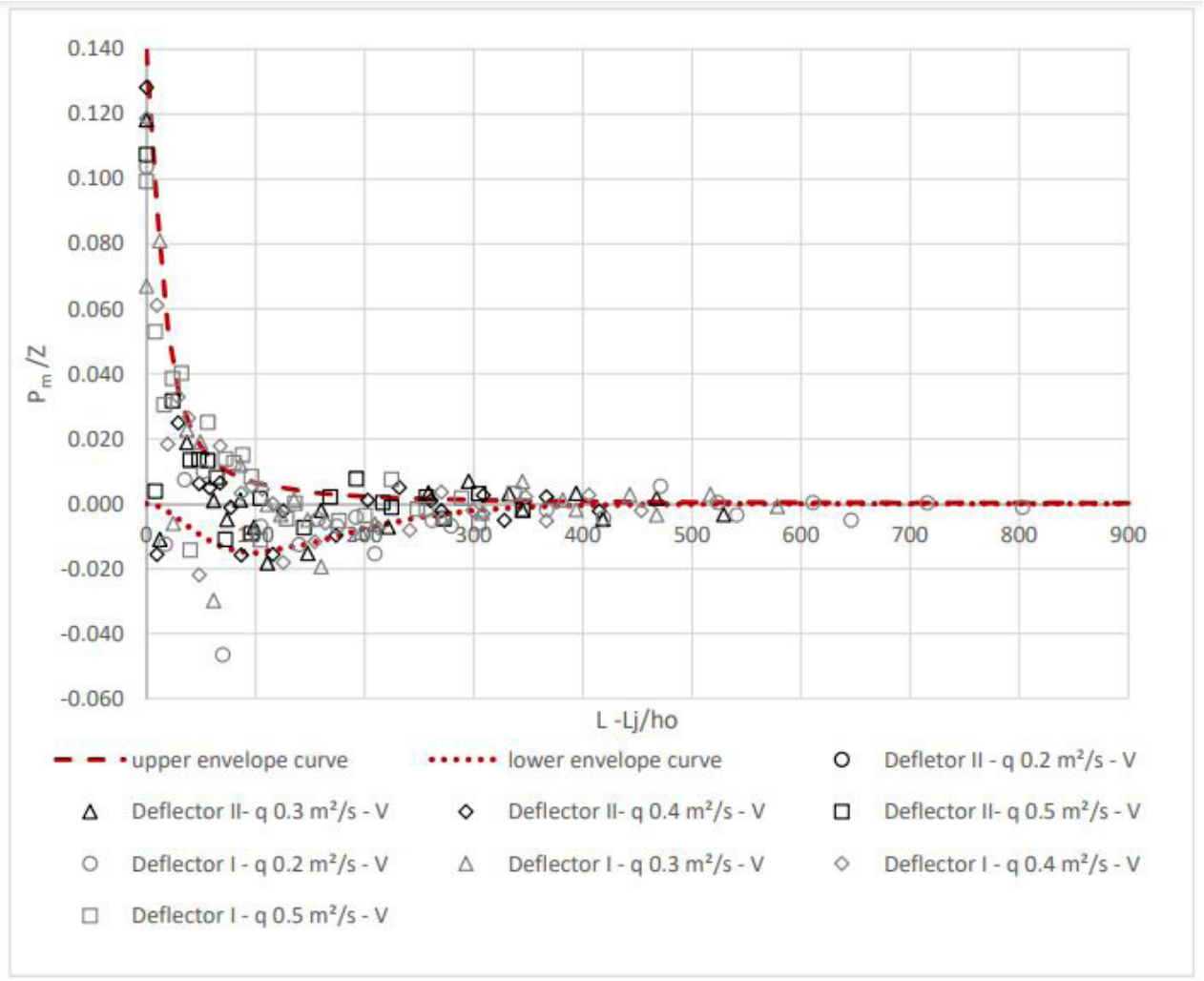

Figure 7. Mean pressures obtained in vertical faces of steps for deflector I and II, dimensionless. 
the pressures at a free surface chute. Information involving the amount of air inserted by the aerator $(\beta)$ will be presented next.

\section{Characteristics positions}

The characteristic positions of the flow, as shown in Figure 8 (as a scheme) and in Figure 9 (physical model photographs),

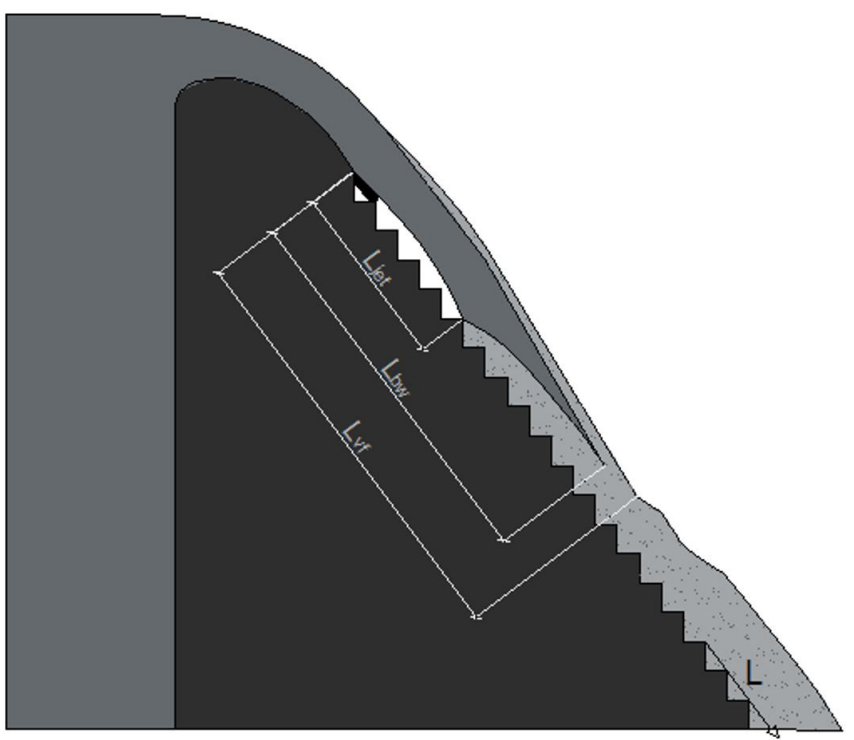

Figure 8. Characteristic position on the flow as a scheme. were presented in Figure 10a, b and c in model dimensions, as a function of specific discharge, and in Figure 10d, e and $f$, represented by $\frac{L_{\mathrm{x}}}{\mathrm{h}_{\mathrm{o}}}$ as a function of the Froude number, where $\mathrm{Lx}$ is the length from the beginning of the deflector to the position along the chute.

In Figures 8 and 9, as described by Novakoski et al. (2020), the jet impact $\left(\mathrm{L}_{\mathrm{jet}}\right)$ is the point where the jet originated by the deflector reaches the chute, causing a peak of mean pressures. The blackwater end $\left(\mathrm{L}_{\mathrm{bw}}\right)$, is the place where the blackwater core ends and gradually varied flow beginning $\left(\mathrm{L}_{\mathrm{vf}}\right)$ is the position where the gradually varied flow begins. The jet impact was determined through mean pressures at the position where the maximum pressure peak on horizontal face of the step was observed. $\mathrm{L}_{\mathrm{bw}}$ and $\mathrm{L}_{\mathrm{vf}}$ were visually verified: $\mathrm{L}_{\mathrm{bw}}$ was identified at the point where the blackwater core could not be seen from the lateral view of the model and $\mathrm{L}_{\mathrm{vf}}$ position where waves and droplets start to be seen in the frontal view of the model. $\mathrm{L}_{\text {jet }}$ was the only characteristic position that presented differences between deflector I and II, while $\mathrm{L}_{\mathrm{bw}}$ and $\mathrm{L}_{\mathrm{vf}}$ weren't significantly influenced by deflector geometry.

The gradually varied flow beginning was compared with the inception point of natural aeration, considering the same flow characteristics at the same physical model. Such a comparison considers that the $\mathrm{L}_{\mathrm{vf}}$ position in induced aeration flow is originated in the region where the boundary layer reaches the free surface, due to the macro-turbulence imposed by the presence of steps, as well as the inception point of natural aeration on the NA condition. The result is shown in Figure 11. The induced aeration does not result in a significant change in $\mathrm{L}_{\mathrm{vf}}$, which agrees with studies such
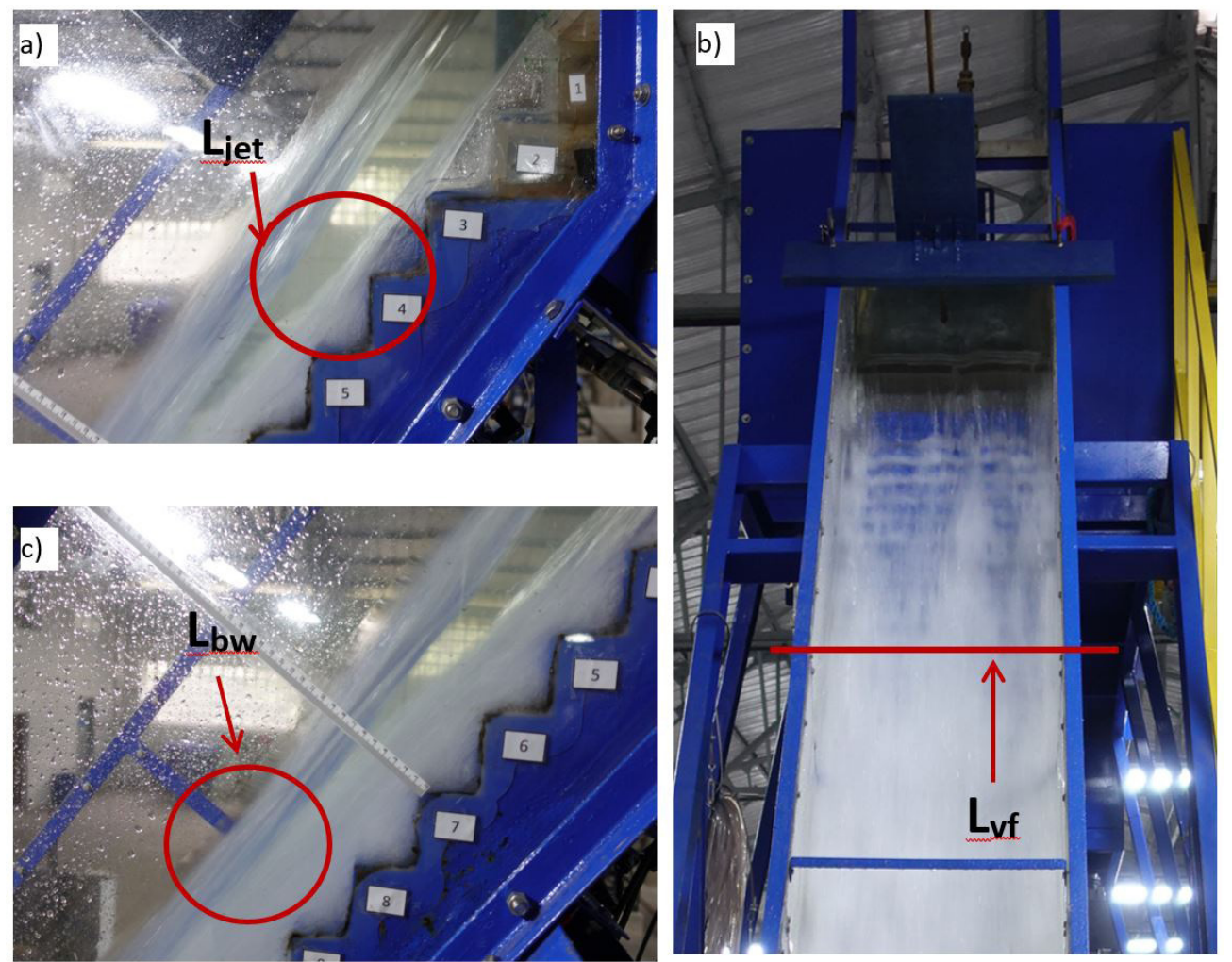

Figure 9. Characteristic position on the flow as physical model photographs (a) jet impact (b) gradually varied flow beginning and (c) blackwater end. 

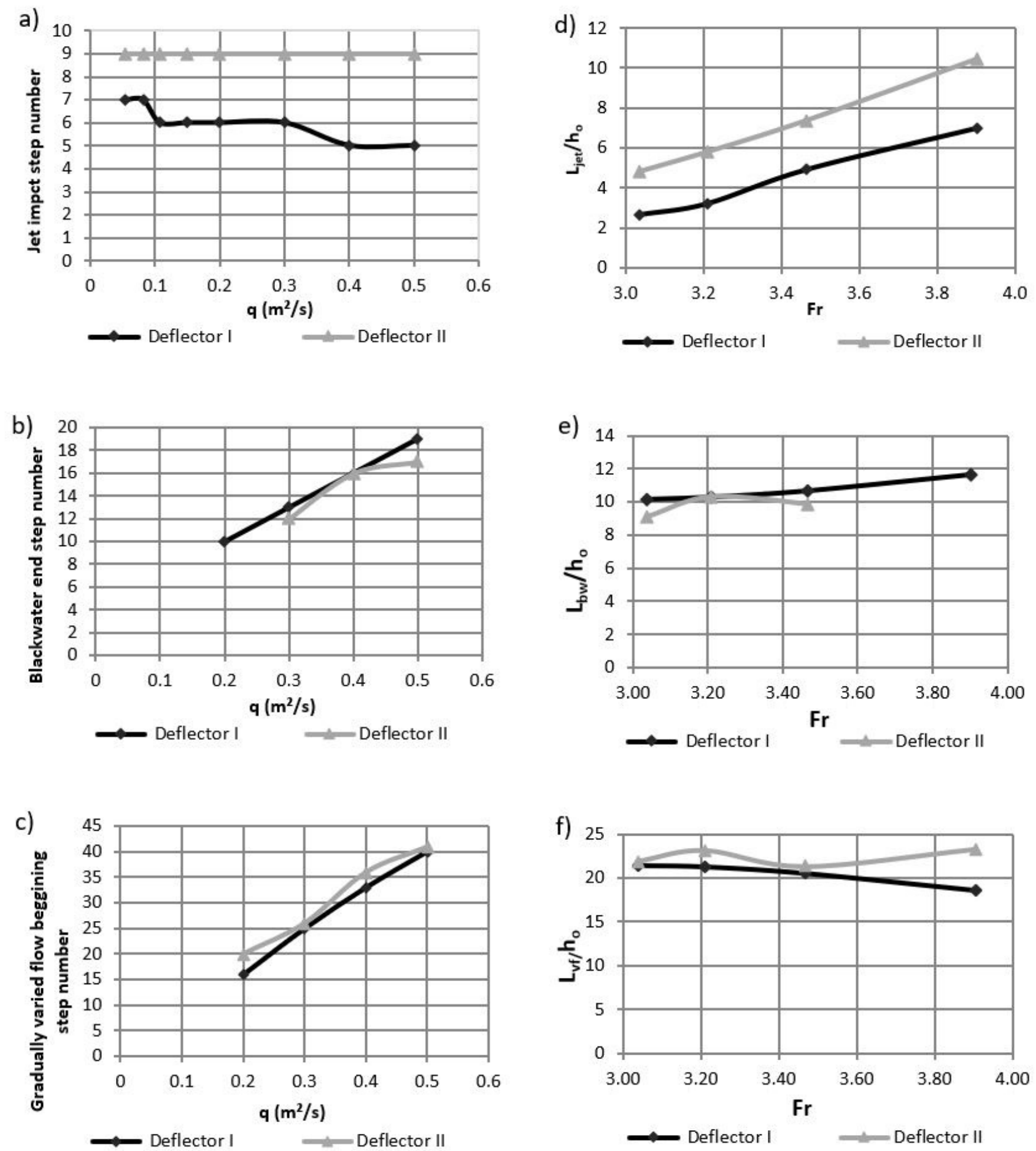

Figure 10. Characteristics position on the flow.

as Pfister et al. (2006b) mainly considering that the measurement was done visually. It was observed that the largest relative deviation concerning the natural aeration was $11 \%$ referring to a flow of $0.2 \mathrm{~m}^{2} / \mathrm{s}$, which is equivalent to 2 steps in the model. However, the presence of air near the pseudo-bottom when the flow reaches the steps, which means that, although the inception point is not anticipated, there is induced aeration through the flow inferior surface in regions where there is only water in natural aeration.

\section{Air entrainment coefficient}

The air entrainment coefficient obtained with the two deflectors tested is shown in Figure 12a, in which can be noted that $\beta$ values decrease as the discharge increases. Therefore, a higher $\beta$ is related to lower discharges, the lower value measured being approximately $2 \%$ and the maximum above $8 \%$. The $\beta$ coefficients related to deflector I are inferior than the coefficients 


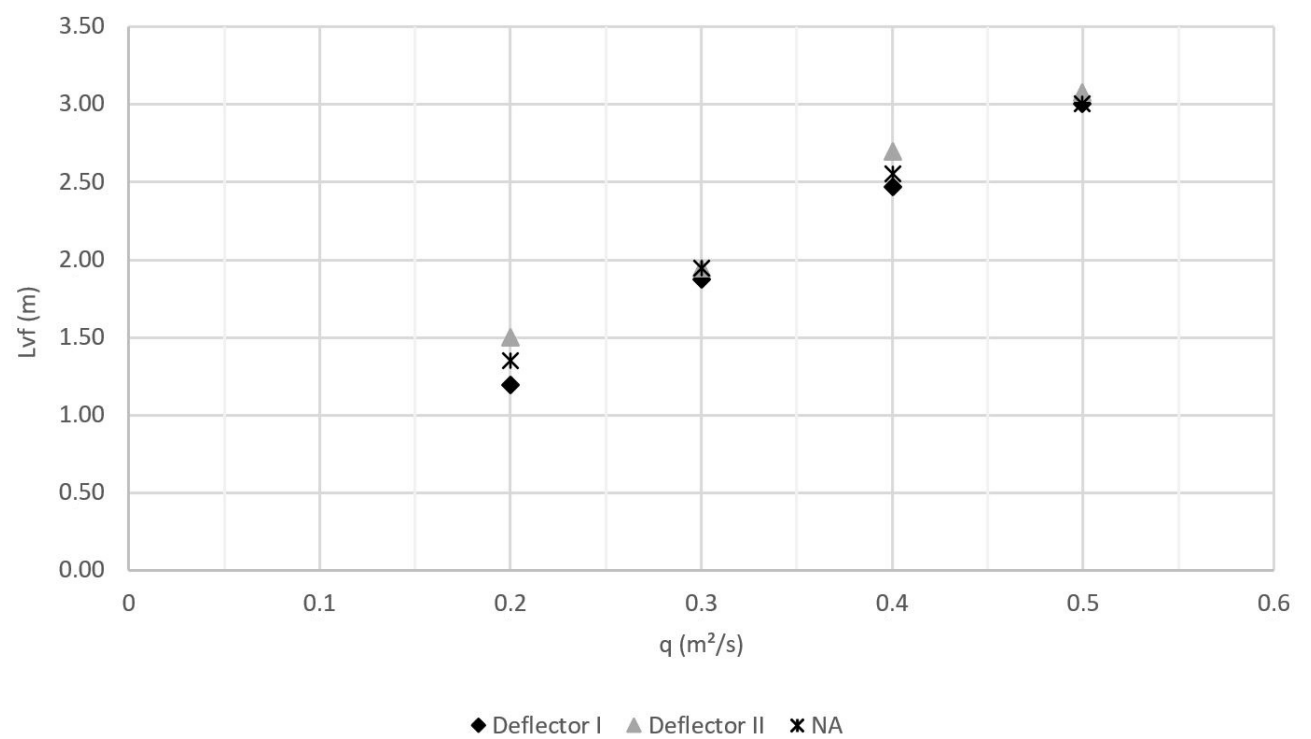

Figure 11. Comparison of the gradually variated flow beginning between induced and natural aeration.
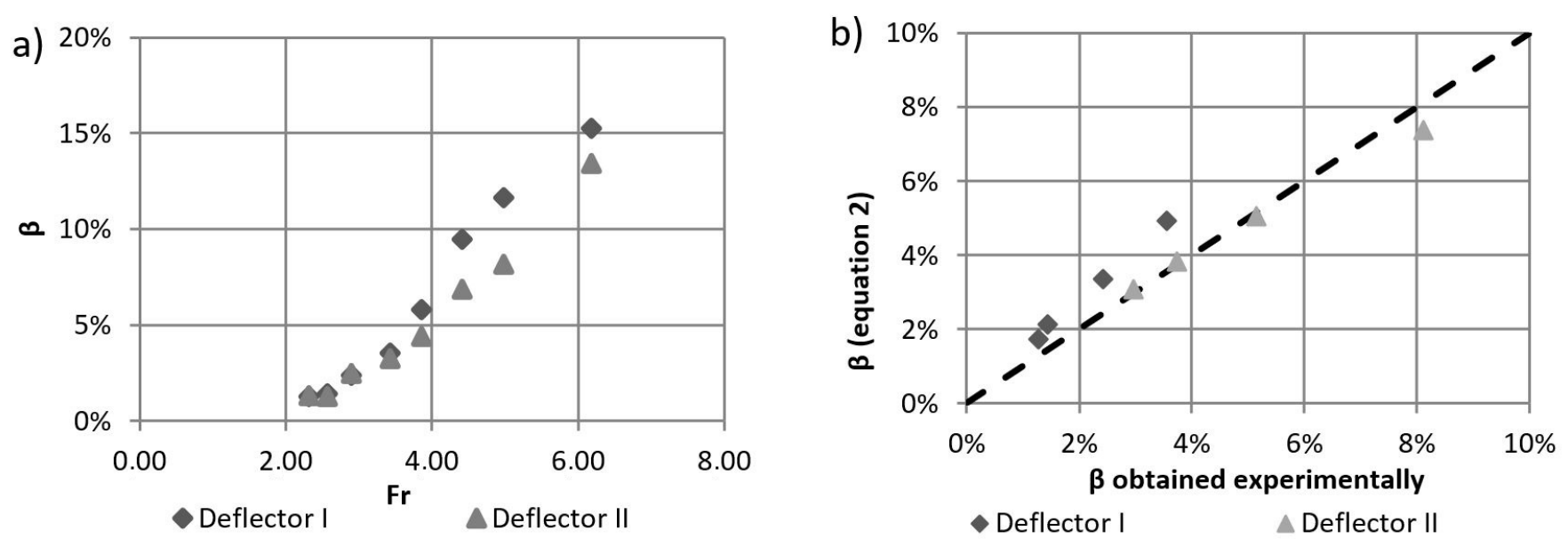

Figure 12. Air entrainment coefficient measured (a) for the two deflectors tested and (b) compared to the calculated with Equation 2 , by Terrier (2016).

related to deflector II. This result agrees with the jet impact result, whereas a longer jet provides a higher $\beta$. The $\beta$ values obtained experimentally were compared with values calculated using Equation 2, by Terrier (2016) (Figure 12b). The air entrainment coefficient experimentally obtained for both deflectors is close to the calculated ones. That regards especially the results of deflector II, which presented a maximum dispersion of $9 \%$. These results indicated that Equation 2 can be used for the current research flow and for the geometry of the tested deflectors.

\section{CONCLUSIONS}

The purpose of the present work was to analyze mean pressures, flow behavior and air entrainment coefficient in an induced aeration flow over stepped spillways. The main conclusions are presented bellow.

\section{Mean pressures}

The jet impact leads to a positive peak of mean pressures in both the horizontal and vertical faces of the steps. Considering deflector II, the jet impact occurs downstream compared to deflector I and, consequently, the end of its influence also occurs downstream for deflector II compared to deflector I. Despite the influence of the jet impact region, the mean pressures with induced aeration - regarding the geometry of the two deflectors tested - did not present significant differences from flows with natural aeration, differently from the expected according to literature. A possible reason may be that the studies found in the bibliography that demonstrate the increase of mean pressure with the introduction of air were performed in closed conduits where the flow cannot expand with air entrainment. On the contrary, the present research was conducted in a free surface chute where the 
flow depth increases with air entrainment. In this situation, maybe the air concentration is not sufficient to change the mean pressures.

Considering the forecast of mean pressures of induced aeration flow, four equations were developed. Equation 6 and 7 allow estimating superior and inferior mean pressures limits on the horizontal faces of steps and Equation 8 and 9 were adjusted to the mean pressure data on the vertical faces of steps.

\section{Flow behavior}

The flow behavior observed was the same as presented by Novakoski et al. (2020). The jet impact position verified was downstream from deflector II as related to deflector I. The other characteristic positions were not significantly modified considering the different deflectors.

\section{Air entrainment coefficient}

In agreement with the jet impact position, the air entrainment coefficient is higher for deflector II. The values obtained follow the data tendency of Terrier (2016) and the equation proposed by the author (Equation 2, as a function of jet impact length) can be used.

\section{ACKNOWLEDGEMENTS}

The authors would like to thanks to the Coordenação de Aperfeiçoamento de Pessoal de Nível Superior (CAPES), Conselho Nacional de Desenvolvimento Científico e Tecnológico (CNPq, Brazil), the Instituto de Pesquisas Hidráulicas (IPH/UFRGS, Brazil) and FURNAS Centrais Elétricas (Brazil) for providing the conditions and the financial support for the experimental works. The authors are grateful to professor Jorge Saldanha Gonçalves Matos for the valuable suggestions and contributions for the data analysis.

\section{NOTATION}

$\beta=$ air entrainment coefficient;

$\Delta_{\mathrm{p}}=$ subpressure under the jet;

$\gamma=$ water specific weight;

$\varrho=$ fluid density;

$\nu=$ kinematic viscosity of the flow

$\mathrm{F}_{\mathrm{r}}=$ Froude number;

$\mathrm{g}=$ acceleration of gravity;

$\mathrm{h}_{\mathrm{c}}=$ critical flow depth;

$\mathrm{h}_{\mathrm{o}}=$ flow depth at intersection of ogee and deflector;

$\mathrm{L}=$ distance, along the chute, from first step to the point analyzed;

$\mathrm{L}_{\mathrm{bw}}=$ distance, along the chute, from first step to blackwater end position;

$\mathrm{L}_{\mathrm{jet}}=$ distance, along the chute, from first step to jet impact;

$\mathrm{L}_{\mathrm{vf}}=$ distance, along the chute, from first step to gradually varied

flow beginning;

$\mathrm{L}_{\mathrm{x}}=$ characteristic position along the chute;

$\mathrm{P}_{\mathrm{m}}=$ mean pressures;

$\mathrm{P}_{\mathrm{v}}^{\mathrm{m}}=$ fluid vapor pressure; $\mathrm{q}=$ specific discharge;

$\mathrm{Q}_{\mathrm{a}}=$ air flow discharge;

$\mathrm{Q}_{\mathrm{w}}=$ water flow discharge;

$\mathrm{V}_{\mathrm{o}}=$ flow velocity at intersection of ogee and deflector;

$\mathrm{R}_{\mathrm{e}}=$ Reynolds number;

$\mathrm{W}_{\mathrm{e}}=$ Webber number;

$Z^{\mathrm{e}}=$ flow energy on the point analyzed.

\section{REFERENCES}

Amador, A. (2005). Comportamiento bidráulico de los aliviaderos escalonados em presas de hormigón compactado (Phd thesis). Unicersitat Politècnica de Catalunya, Barcelona.

Amador, A., Sánchez-Juny, M., \& Dolz, J. (2009). Developing flow region and pressure fluctuations on steeply sloping stepped spillways. Journal of Hydraulic Engineering, 135(12), 1092-1100. http:/ / dx.doi.org/10.1061/(ASCE)HY.1943-7900.0000118.

Boes, R. M., \& Hager, W. H. (2003). Two-phase flow characteristics of stepped spillways. Journal of Hydraulic Engineering, 129(9), 661-670. http://dx.doi.org/10.1061/(ASCE)0733-9429(2003)129:9(661).

Canellas, A. V. B., Priebe, P dos S., Ferla, R., Novakoski, C. K., Reginatto, A. C., Prá, D. M., Sanagiotto, D. G., Endres, L. A. M., \& Marques, M. G. (2017). Nova proposta de análise adimensional da distribuição de pressões ao longo da calha de um vertedouro em degraus. In Anais do XXII Simpósio Brasileiro de Recursos Hídricos. Florianópolis: ABRH.

Chamani, M. R., \& Rajaratnam, N. (1999). Characteristics of skimming flow over stepped spillays. Journal of Hydraulic Engineering, 125(4), 361-368. http://dx.doi.org/10.1061/(ASCE)07339429(1999)125:4(361).

Chanson, H. (1994). Comparison of energy dissipation between nappe and skimming flow regimes on stepped chutes. Journal of Hydraulic Research, 32(2), 213-218. http://dx.doi.org/10.1080/00 221686.1994.10750036.

Chanson, H. (2001). Hydraulic design of stepped spillways and downstream energy dissipation. Dam Engineering, 11(4), 205-242.

Christodoulou, G. (1993). Energy dissipation on stepped spillways. Journal of Hydraulic Engineering, 119(5), 644-650. http://dx.doi. org/10.1061/(ASCE)0733-9429(1993)119:5(644).

Dong, Z., Chen, L., \& Ju, W. (2007). Cavitation characteristics of high velocity flow with and without aeration on the order of $50 \mathrm{~m} / \mathrm{s}$. Journal of Hydrodynamics, 19(4), 429-433. http://dx.doi. org/10.1016/S1001-6058(07)60136-X.

Dong, Z., Wang, J., Vetsch, D. F., Boes, R. M., \& Tan, G. (2019). Numerical simulation of air-water two phase flow on stepped spillways behind $\mathrm{x}$-shaped flaring gate piers under very high unit discharge. Water (Basel), 11(10), 1956. http:/ /dx.doi.org/10.3390/ w11101956. 
Ferla, R., Novakoski, C. K., Priebe, P. S., Daí Prá, M., Marques, M. G., \& Teixeira, E. D. (2021). Stepped spillways with aerators: hydrodynamic pressures anda ir entrainment. Revista Brasileira de Recursos Hídricos, 26, e04.

Frizell, K. W., Renna, F. M., \& Matos, J. (2013). Cavitation potential of flow on stepped spillways. Journal of Hydraulic Engineering, 139(6), 630-636. http://dx.doi.org/10.1061/(ASCE)HY.1943-7900.0000715.

Gomes, J. F. (2006). Campo de pressões: condições de incipiência à cavitação em vertedouros em degraus com declividade 1V:0,75H (Phd thesis). Programa de Pós-graduação em Recursos Hídricos e Saneamento Ambiental, Universidade Federal do Rio Grande do Sul, Porto Alegre.

Kobus, H. (1984). Local air entrainment and detrainment. In Proceedings of the Symposium on Scale Effects in Modelling Hydraulic Structures. Stuttgart: IAHR.

Koen, J., Bosman, D. E., \& Basson, G. R. (2019). Artificial aeration of stepped spillways by crest piers and flares for the mitigation of cavitation damage. Journal of the South African Institution of Civil Engineering, 61(2), 28-38. http://dx.doi.org/10.17159/2309$8775 / 2019 / v 61$ n2a3.

Kökpınar, M. A., \& Gogus, M. (2002). High speed jet flows over spillway aerators. Canadian Journal of Civil Engineering, 29(6), 885898. http://dx.doi.org/10.1139/102-088.

Koschitzky, H. P., Westrich, B., \& Kobus, H. (1984). Effects of model configuration, flow conditions and scale in modelling spillway aeration grooves. In Proceedings of the Symposium on Scale Effects in Modelling Hydraulic Structures. Stuttgart: IAHR.

Ma, F., \& Wu, J.-H. (2021). Hydraulics of abrupt contraction aerator on stepped chutes. Journal of Hydraulic Research, http:/ / dx.doi.org/10.1080/00221686.2020.1780500.

Matos, J. S. G. (1999). Emulsionamento de ar e dissipação de energia do escoamento em descarregadores em degraus (Phd thesis). Instituto Superior Técnico, Universidade Técnica de Lisboa, Lisboa.

Matos, J., \& Meireles, I. (2014). Hydraulics of stepped weirs and dam spillways: engineering challenges, labyrinths of research. In Proceedings of the 5th International Symposion on Hydraulic Structures. Brisbane: IAHR. http://dx.doi.org/10.14264/uql.2014.11.

Mojtaba, S., Jahromi Habib, M., Bajestan Mahmood, S., Alireza, M., \& Heidar Ali, K. (2015). Experimental study of effect of installing deflector on replacement of inception point of air entrainment in stepped spillways. Journal of Scientific Research and Development, 2(4), 11-16.

Novakoski, C. K., Ferla, R., Dai Prá, M., Canellas, A. V. B., Marques, M. G., \& Teixeira, E. D. (2020). Stepped spillway with pre-aeration by a deflector: flow characteristics. Revista Brasileira de Recursos Hídricos, 25, e26. http://dx.doi.org/10.1590/23180331.252020190051.
Novakoski, C. K., Priebe, P. S., Canellas, A. V. B., Saraiva, L. S., Daí Prá, M., Sanagiotto, D. G., Osmar, F. M., Pinto, L. C. S., Marques, M. G., \& Matos, J. (2018). Extreme negative pressures and cavitation tendency on steeply sloping stepped spilways. In Proceedings of the Third International Dam World Conference. Foz do Iguaçu: IBRACON.

Ohtsu, I., Yasuda, Y., \& Takahashi, M. (2004). Flow characteristics of skimming flows in stepped channels. Journal of Hydraulic Engineering, 130(9), 860-869. http://dx.doi.org/10.1061/(ASCE)07339429(2004)130:9(860).

Osmar, F. M., Canellas, A. V. B., Priebe, P. S., Saraiva, L. S., Teixeira, E. D., \& Marques, M. G. (2018). Analysis of the longitudinal distribution of pressures near the ends of the vertical and horizontal faces in stepped spillway of slope 1V:0.75H. Revista Brasileira de Recursos Hidricos, 23(0), e4. http://dx.doi.org/10.1590/23180331.0318170057.

Peterka, A. J. (1953). The effect of entrained air on cavitation pitting. Minneapolis: International Association for Hydraulic Research and Hydraulics Division.

Pfister, M., \& Hager, W. H. (2010). Chute aerators. II: hydraulic design. Journal of Hydraulic Engineering, 136(6), 360-367. http:// dx.doi.org/10.1061/(ASCE)HY.1943-7900.0000201.

Pfister, M., \& Hager, W. H. (2011). Self-entrainment of air on stepped spillways. International Journal of Multiphase Flow, 37(2), 99-107. http://dx.doi.org/10.1016/j.ijmultiphaseflow.2010.10.007.

Pfister, M., Hager, W. H., \& Minor, H. (2006a). Bottom aeration of stepped spillways. Journal of Hydraulic Engineering, 132(8), 850-853. http://dx.doi.org/10.1061/(ASCE)0733-9429(2006)132:8(850).

Pfister, M., Hager, W. H., \& Minor, H. (2006b). Stepped chutes: pre-aeration and spray reduction. International Journal of Multiphase Flow, 32(2), 269-284. http://dx.doi.org/10.1016/j. ijmultiphaseflow.2005.10.004.

Priebe, P. S., Ferla, R., Novakoski, C. K., Abreu, A. S., Teixeira, E. D., Dai Prá, M., \& Marques, M. G. (2021). Influence of aeration induced by piers on the starting position of the flow aeration and extreme pressures in stepped spillways. Revista Brasileira de Recursos Hidricos, 26.

Russell, S. O., \& Sheehan, G. J. (1974). Effect of entrained air on cavitation damage. Journal of Canadiam Engeneering, 1(1), 97-107. http://dx.doi.org/10.1139/174-008.

Rutschmann, P., \& Hager, W. H. (1990). Air entrainment by spillway aerators. Journal of Hydraulic Engineering, 116(6), 765-782. http://dx.doi.org/10.1061/(ASCE)0733-9429(1990)116:6(765).

Sánchez-Juny, M., Bladé, E., \& Dolz, J. (2007). Pressures on a stepped spillway. Journal of Hydraulic Research, 45(4), 505-511. http://dx.doi.org/10.1080/00221686.2007.9521785. 
Semenkov, V. M., \& Lentyaev, L. D. (1973). Spillway with nappe aeration. Hydrotechnical Construction, 7(5), 436-441. http://dx.doi. org/10.1007/BF02376344.

Simões, A. L. A., Schulz, H. E., Porto, R., \& Gulliver, J. S. (2013). Free-surface profiles and turbulence characteristics in skimming flows along stepped chutes. Journal of Water Resource and Hydraulic Engineering., 2(1), 1-12.

Takahashi, M., Yasuda, Y., \& Ohtsu, I. (2005). Effect of Reynolds number on characteristics of skimming flows in stepped chanells. In Proceedings of the XXXI LAHR Congress. Seou: IAHR.

Tassinari, L. C. S., Sanagiotto, D. G., Marques, M. G., Lauffer, L. L., \& Trierweiler Neto, E. F. (2020). Combination of experimental and numerical approaches to determine the main characteristics of skimming flow in stepped spillways. Revista Brasileira de Recursos Hidricos, 25, e3. http://dx.doi.org/10.1590/2318-0331.252020190070.

Terrier, S. (2016). Hydraulic performance of stepped spillway aerators and related downstream flow features (Communication, No. 63). Lausanne: Laboratoire de Constructions Hydrauliques, Ecole Polytechnique Fédérale de Lausanne.

Tozzi, M. J. (1992). Caracterização/comportamento de escoamentos em vertedouros com paramento em degraus (Tese de doutorado). Escola Politécnica, Universidade de São Paulo, São Paulo.

Zamora, A. S., Pfister, M., Hager, W. H., \& Minor, H. (2008). Hydraulic performance of step aerator. Journal of Hydraulic Engineering, 134(2), 127-134. http:/ /dx.doi.org/10.1061/(ASCE)07339429(2008)134:2(127).

Zhang, G., Chanson, H., \& Wang, H. (2016). Total pressure fluctuations and two-phase flow turbulence in self-aerated stepped chute flows. Flow Measurement and Instrumentation, 51, 8-20. http:/ / dx.doi.org/10.1016/j.flowmeasinst.2016.08.007.

\section{Authors contributions}

Carolina K. Novakoski: Methodology elaboration, data analysis, graphics elaborations, bibliographic review, text elaboration.

Rute Ferla: Methodology elaboration, data analysis, text review.

Priscila dos Santos Priebe: Methodology elaboration, data analysis, text review.

Aline Saupe Abreu: Data analysis, text review.

Marcelo G. Marques: Model conception, methodology elaboration, data analysis, text review.

Maurício Dai Prá: Methodology elaboration, data analysis, text review.

Alba V. B. Canellas: Model conception, data analysis, text review.

Eder D. Teixeira: Data analysis, text review.

Editor-in-Chief: Adilson Pinheiro

Associated Editor: Iran Eduardo Lima Neto 


\section{APPENDIX A. SUB PRESSURE ANALYSIS.}

Pfister \& Hager (2011) indicated that sub pressures below 10\% of flow depth at the beginning of the deflector do not influence the flow behavior. Figure A1 shows the relation between sub pressure measured on the horizontal face of the first step (immediately downstream from the deflector) and flow depth, as a function of the tested discharge and Pfister \& Hager (2011) limit. All the present research data are above the Pfister \& Hager (2011) indication, which allows the conclusion that the sub pressure doesn't have to be considered.

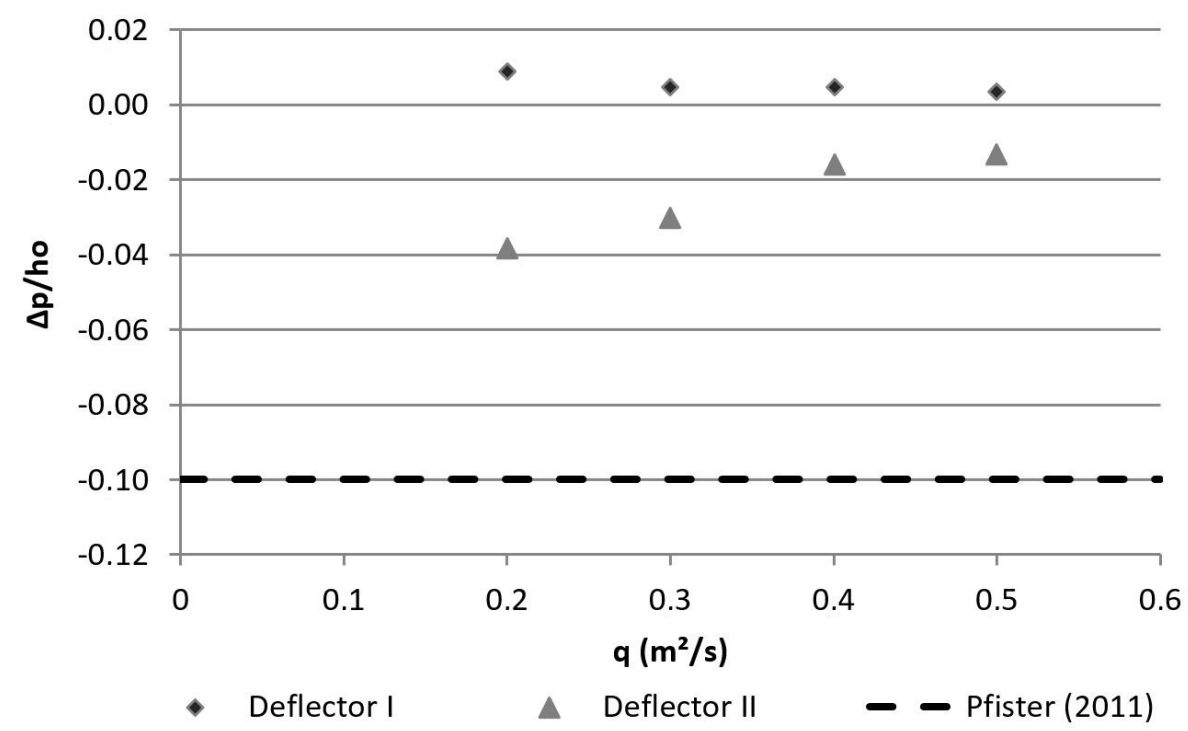

Figure A1. Sub pressures measured on horizontal face of the first step downstream the deflector. 